\title{
Management of choroidal metastases from breast carcinoma
}

\author{
I. M. MACMIGHAEL \\ Department of Ophthalmology, Royal Infirmary of Edinburgh
}

Secondary deposits from malignant tumours which invade the eye usually appear in the choroid. There are difficulties, however, in assessing the exact incidence of choroidal metastases, which have led to wide variations in quoted figures. Figures from Ophthalmic Clinics range from I : 35,000 cases seen (Payne, 1932) to I : 147,000 (Stallard, 1933), but these tend to minimize the overall incidence. Most patients with choroidal metastases are now usually referred to radiotherapy departments and researches from these departments have led to more meaningful figures. Godtfredsen (1944) found six such cases among 8,7 1 2 patients $(0 \cdot 69: 1,000)$ in Copenhagen, where there was close co-operation between ophthalmic and radiotherapy units.

Most authors are agreed that the breast is the commonest primary site of choroidal metastases; Ask (1934) quoted breast primaries as being responsible for 60 to 70 per cent. of cases in an extensive review. Willis (1952) found 78 per cent. out of 140 patients to have a breast primary. Cade (1956) found eleven cases of choroidal metastases from I 35 patients who had had adrenalectomy for breast carcinoma.

The purpose of this paper is to report six cases of choroidal metastases from breast primaries, which were referred to the Ophthalmic Clinic, Royal Infirmary of Edinburgh, between 1959 and 1968 . The emphasis is on the treatment of these patients, giving, where possible, quantitative assessment of visual function before and after conservative therapy. It is also the intention to show that the survival time, i.e. the time between the diagnosis of the choroidal metastases and death, may make such treatment worthwhile.

\section{Present study}

The clinical details of six patients are shown in Tables I and II. Three patients (Cases 2, 4, and 6) were noted to have widespread secondaries before the choroidal metastases were seen; one (Case 6) was seen terminally, and the eye was enucleated post mortem and confirmed the clinical diagnosis.

Five patients received treatment. Four (Cases I, 2, 3, and 4) were treated conservatively with radiotherapy, two having endocrine treatment in addition. The fifth (Case 5) had the affected eye enucleated because of secondary glaucoma before the diagnosis was made. This was the only case with extraocular extension of the tumour and she subsequently received radiotherapy to the orbit.

Only the two enucleated eyes already mentioned (Cases 5 and 6) had histological confirmation of the diagnosis. The four clinically diagnosed patients had flattish grey ill-defined choroidal lesions associated with shallow retinal detachments. They all had proven histories of breast carcinoma. Hogan (1964), discussing the differential diagnosis of metastatic intraocular tumours, stated that the principal method of establishing the diagnosis was based on observation of a primary tumour elsewhere in the body. These four patients (Cases I, 2, 3, and 4) had good functional results with conservative therapy and two of them (Cases I and 2) had deposits in both eyes. Of the six affected eyes in these four patients, one deteriorated, two remained unchanged, and three improved after therapy (Table II). 
Table I Clinical particulars of six patients

\begin{tabular}{|c|c|c|c|c|c|c|}
\hline $\begin{array}{l}\text { Case } \\
\text { No. }\end{array}$ & $\begin{array}{l}\text { Age } \\
(y r s)\end{array}$ & $\begin{array}{l}\text { Breast } \\
\text { carcinoma } \\
\text { diagnosed }\end{array}$ & Treatment of breast & Stage & $\begin{array}{l}\text { Choroidal } \\
\text { secondary } \\
\text { noted }\end{array}$ & Outcome \\
\hline $\mathbf{I}$ & 43 & $5 \cdot 9 \cdot 47$ & $\begin{array}{l}\text { Simple mastectomy } \\
\text { Radiotherapy-left breast } \\
\text { Radiotherapy-ovaries }\end{array}$ & II & 5.2 .59 & $\begin{array}{l}\text { Died ( } 17.2 .6 \text { I ) } \\
\text { Cerebral metastases }\end{array}$ \\
\hline 2 & 43 & March, I96o & $\begin{array}{l}\text { Simple mastectomy } \\
\text { *Radiotherapy-right breast } \\
\text { Radiotherapy-ovaries (1962) }\end{array}$ & III & $4 \cdot 9 \cdot 62$ & $\begin{array}{l}\text { Died (1 2.10.63) } \\
\text { Lung metastases before } \\
\text { choroidal secondary }\end{array}$ \\
\hline 3 & $5^{2}$ & 14.1 .62 & $\begin{array}{l}\text { Simple mastectomy } \\
\text { Radiotherapy—right breast }\end{array}$ & II & $8.1 \times 63$ & $\begin{array}{l}\text { Died }(4 \cdot 7 \cdot 64) \\
\text { Pelvic metastases }\end{array}$ \\
\hline 4 & 57 & Sept., I 962 & $\begin{array}{l}\text { Simple mastectomy } \\
\text { Radiotherapy-left breast }\end{array}$ & $\mathbf{I}$ & I.9.67 & $\begin{array}{l}\text { Died (16.1 } 2.67 \text { ) } \\
\text { Lung metastases before } \\
\text { choroidal secondary }\end{array}$ \\
\hline 5 & 54 & Nov., 1963 & $\begin{array}{l}\text { Radiotherapy-right breast } \\
\text { Simple mastectomy } \\
\text { one year later }\end{array}$ & III & $29 \cdot 5.68$ & $\begin{array}{l}\text { Alive (March, I } 969 \text { ) } \\
\text { No sign of other } \\
\text { metastases }\end{array}$ \\
\hline 6 & 45 & I 959 & Radical mastectomy & & $\begin{array}{l}2 \text { weeks } \\
\text { before } \\
\text { death }\end{array}$ & $\begin{array}{l}\text { Died } \\
\text { Terminal case }\end{array}$ \\
\hline
\end{tabular}

Table II Ophthalmological lesions and treatment in six patients

\begin{tabular}{|c|c|c|c|c|c|c|}
\hline \multirow{2}{*}{$\begin{array}{l}\text { Case } \\
\text { No. }\end{array}$} & \multirow{2}{*}{$\begin{array}{l}\text { Choroidal } \\
\text { lesion }\end{array}$} & \multirow{2}{*}{$\begin{array}{l}\text { Visual acuity } \\
\text { at diagnosis }\end{array}$} & \multicolumn{2}{|l|}{ Treatment } & \multirow{2}{*}{$\begin{array}{l}\text { Last visual } \\
\text { acuity }\end{array}$} & \multirow[b]{2}{*}{ Survival* } \\
\hline & & & $\begin{array}{l}\text { Radiotherapy } \\
\text { to orbit }\end{array}$ & Endocrine therapy & & \\
\hline $\mathbf{I}$ & Bilateral & $\begin{array}{l}\text { Right } 6 / 18 \\
\text { Left } 6 / 9\end{array}$ & $\begin{array}{l}\mathbf{I}, 000 \text { rads } \\
\mathbf{I}, 000 \text { (Rpt.) } \\
\mathbf{I}, 500 \\
\mathbf{I}, 000 \text { (Rpt.) }\end{array}$ & $\begin{array}{l}\text { Stilboestrol } 5 \mathrm{mg} \text {. } \\
\text { three times a day }\end{array}$ & $\begin{array}{l}\text { Right } 6 / 18 \\
\text { Left } 6 / 60\end{array}$ & $2 \mathrm{yrs}$ \\
\hline 2 & Bilateral & $\begin{array}{l}\text { Right } 6 / 60 \\
\text { Left } 6 / 9\end{array}$ & $\begin{array}{l}\text { 1,000 rads } \\
\text { nil }\end{array}$ & - & $\begin{array}{l}\text { Right } 6 / 9 \\
\text { Left } 6 / 6\end{array}$ & I $3 \mathrm{mths}$ \\
\hline 3 & Left & $\begin{array}{l}\text { Right } 6 / 6 \\
\text { Left } 6 / 6\end{array}$ & 2,500 rads & - & $\begin{array}{l}\text { Right } 6 / 6 \\
\text { Left } 6 / 6\end{array}$ & $8 \mathrm{mths}$ \\
\hline 4 & Right & $\begin{array}{l}\text { Right } 2 / 60 \\
\text { Left } 6 / 5\end{array}$ & I,250 rads & $\begin{array}{l}\text { Deca-Durabolin } \\
\text { I } 00 \mathrm{mg} \text {. alternate } \\
\text { weeks }\end{array}$ & $\begin{array}{l}\text { Improved with } \\
\text { better field }\end{array}$ & 3 mths \\
\hline 5 & Right & $\begin{array}{l}\text { Right } 6 / 12 \\
\text { Left } 6 / 6\end{array}$ & $\begin{array}{l}\text { Enucleation } \\
\text { 1,250 rads } \\
\text { to socket }\end{array}$ & - & & $\begin{array}{l}\text { Surviving } \\
\text { after ro } \\
\text { mths }\end{array}$ \\
\hline 6 & Right & Not recorded & No treatment & & & 2 wks \\
\hline
\end{tabular}

*Time between diagnosis of choroidal metastasis and death 


\section{Treatment}

\section{(I) RADIOTHERAPY}

Cases I, 2, and 4 were treated with a single dose of mega voltage $x$ rays to the affected orbit. The maximum tumour dose ranged from $1,000-1,500$ rads. Case 3 had five doses in the course of a week amounting to a maximum tumour dose of 2,500 rads. $X$ rays were directed from a lateral field to the posterior part of the orbit through a portal varying from $4 \times 4$ to $6 \times 4 \mathrm{~cm}$. One of the bilaterally-affected patients (Case I) had recurrent $\mathrm{c}$ activity in both eyes and was given a further single dose to each orbit. Lead protection was used for the anterior segment of the treated eyes and no radiation damage was reported.

\section{(2) ENDOGRINE}

Case I had had her ovaries ablated by radiotherapy at the time the breast carcinoma was discovered-some 12 years before the appearance of the choroidal metastases. Case 2 had radiotherapy to the ovaries when widespread metastases were discovered, and this coincided with the finding of a choroidal metastasis.

Cases $\mathrm{I}$ and 4 were given additive hormone treatment. Case I had stilboestrol $5 \mathrm{mg}$. three times a day and Case 4 had Deca-Durabolin roo mg. in alternate weeks. The part played by these hormones in the end results is not possible to assess.

\section{Comment}

Treatment of choroidal metastases has in the past often been deferred until such time as enucleation was required because of pain in the affected eye.

Now, however, irradiation with or without endocrine treatment may not only cause the lesion to regress but enable the visual function to improve. This is borne out by several single case reports (Lemoine and McLeod, 1936; Cordes, 1944; Rosselet and Rosselet, I956) and also by the series of Dickson (1958) and the present study (See Table II).

Irradiation for choroidal metastases has been carried out both by local application of radioactive substances (Newell and Harper, 1957) and by $x$ rays. The latter method is easier, and protection of the anterior segment is more successful, especially when using mega voltage $x$ rays (Lederman, 1956). Lederman found no instance of choroidal metastases from the breast in 126 cases of secondary malignant tumours of eye and orbit from his series. There were, however, three patients with orbital metastases from breast primaries which responded reasonably well to radiotherapy.

Irradiation cataract is the most serious hazard to visual function, but with the moderate doses required for the treatment of choroidal lesions this is less likely to occur than when using the higher doses which are required for orbital metastases. The doses used in the present series ( $1,000-1,500$ rads) were lower than in that of Dickson (2,500-5,000 rads). Even 9,000 rads (Rosselet and Rosselet, 1956) has been used for a choroidal metastasis without apparently causing irradiation damage. Of course, these patients rarely survive the 3 years that a radiation cataract may take to develop.

The usual cause of failure of treatment is the permanent impairment of visual function by the extensive retinal detachment which is usually present in the later stages of this condition (Duke-Elder, I966), rather than the failure of the choroidal lesion to regress with radiotherapy.

Selection of patients for treatment does not include terminal cases. However, patients with evidence of other metastases should not be excluded, especially if their ovaries or 
pituitary gland have been ablated when such metastases are found. These patients can live for many months in a normal mental state and good vision is of importance. If choroidal metastases are found and left untreated vision will soon be destroyed through the rapid growth of these lesions and the accompanying retinal detachment (Bedell, 1943). Duke-Elder (1966) also pointed out that $20 \cdot 8$ per cent. of all choroidal metastases become bilateral.

Treatment by enucleation is necessary if the affected eye becomes painful, and this is usually due to secondary glaucoma. However, if early diagnosis is made, conservative therapy by irradiation and endocrine treatment may be successful. Success is measured not only by improvement in vision but also by the preservation of the existing vision at the time of diagnosis of the choroidal lesion. With an untreated rapidly-growing tumour, visual deterioration is inevitable.

\section{Summary}

The incidence of choroidal metastases is briefly reviewed. Six further cases of such metastases from breast carcinoma are reported. Quantitative results of conservative treatment show that irradiation and endocrine therapy can restore or conserve useful visual function.

I am indebted to Prof. G. I. Scott and Dr. C. R. S. Jackson for permission to publish details of their cases. I should also like to thank Dr. J. F. Gullen and Dr. B. A. Bembridge for their help in the preparation of this paper.

\section{References}

AsK, 0. (1934) Acta ophthal. (Kbh.), 12, 308

BEDELl, A. J. (1943) Arch. Ophthal. (Chicago), 30, 25

CADE, s. (1956) Annual Scientific Session, American Cancer Soc. New York

CORDES, F. c. (1944) Amer. F. Ophthal., 27, 1355

DICKSON, R. J. (1958) Ibid., 46, I4

DUKE-ELDER, s. (1966) "System of Ophthalmology", vol. 9, p. 9 1 7. Kimpton, London

GODTFREDSEN, E. (1944) Acta ophthal. (Kbh.), 22, 394

hOGAN, м. J. (1964) In "Ocular and Adnexal Tumors", ed. M. Boniuk, p. 267. Mosby, St. Louis LEDERMAN, M. (1956) Brit. F. Opthal., 40, 592

LEMOINE, A. N., and MCLeod, J. (1936) Arch. Ophthal. (Chicago), 16, 804

NEWELl, F. W., and HARPER, P. v. (1957) Amer. F. Ophthal., 44, 222

PAYNE, B. F. (1932) Tex. St. F. Med., 28, 227

ROSSELET, E., and ROSSELET, P. J. (1956) Radiol. clin. (Basel), 25, 355

STALlard, H. B. (1933) Proc. roy. Soc. Med., 26, 1042

willis, R. A. (1952) "The Spread of Tumours in the Human Body", 2nd ed., p. 296. Butterworth, London 